Review of Educational Research

June 2009, Vol. 79, No. 2, pp. 1008-1043

DOI: $10.3102 / 0034654309332562$

(C) 2009 AERA. http://rer.aera.net

RUNNING HEAD: IDEAS AND IDENTITIES

Ideas and identities: Supporting equity in cooperative mathematics learning

Indigo Esmonde

Indigo Esmonde

Assistant Professor, Mathematics Education

Ontario Institute for Studies in Education

University of Toronto

252 Bloor St. W.

Toronto, ON

M5S 1V6

iesmonde@oise.utoronto.ca 


\begin{abstract}
This review considers research related to mathematics education and cooperative learning, and discusses how teachers might assist students in cooperative groups to provide equitable opportunities to learn. I define equity in this context as the fair distribution of opportunities to learn, and argue that identity-related processes are just as central to mathematical development as content learning. I consider the link between classroom social ecologies, the interactions and positional identities that these social ecologies make available, and student learning. I close by considering unresolved questions in the field and proposing directions for future research.
\end{abstract}




\section{Ideas and identities: Supporting equity in cooperative mathematics learning}

Equity in mathematics education is of growing concern to many education researchers and practitioners, as evidenced by the number of recent publications concerning this topic (see two recent special issues of Mathematical Thinking and Learning (2002 and 2006), as well as National Council of Teachers of Mathematics volumes Jacobs, Becker, \& Gilmer, 2001; NCTM Research Committee, 2005; Secada, 2000; Trentacosta \& Kenney, 1997). In an increasingly technological society, mathematics plays a central part in governmental and corporate decision-making, and these decisions disproportionately affect marginalized people - the very people who are less likely to have access to quality mathematics education. Mathematical knowledge can therefore be an important component of struggles for social justice at home and abroad. In addition, mathematical knowledge is necessary for many careers, and currently serves a key gatekeeping function for academic achievement and high school and college graduation. For these reasons, it is important for mathematics educators find ways to equitably provide powerful mathematics instruction. Equity-oriented reforms in mathematics education must tackle the question of what is learned (i.e., which mathematical topics and processes are important for students to learn?), as well as how it is learned. In this review, I focus on pedagogies for equity in mathematics education; specifically, I consider cooperative group work in mathematics classrooms.

Cooperative learning is one technique that is often recommended to promote more equitable learning environments in mathematics (R. Gutierrez, 2002; Weissglass, 2000). Cooperative learning is a component of many efforts at reform in mathematical 
educational contexts (de Corte, 2004). Advocates argue that it fosters learning of academic content and social skills (Antil, Jenkins, Wayne, \& Vadasy, 1998; Cohen, 1994; Johnson \& Johnson, 1991; Slavin, 1996; Webb \& Palincsar, 1996), supports democratic and social justice goals (Cotton, 2001), and leads to greater inter-group harmony (Aronson \& Bridgeman, 1979; Slavin \& Cooper, 1999). While these benefits are undoubtedly desirable, they are by no means guaranteed. In cooperative learning environments, students may learn incorrect mathematical strategies and undesirable social interactional styles (Good, McCaslin, \& Reys, 1992). It is therefore critical that mathematics classrooms that use cooperative learning be carefully structured. Empirical research on cooperative learning has built a strong foundation of knowledge about the conditions that support group work (for comprehensive reviews, see Cohen, 1994;

O'Donnell, 2006; Slavin, 1996; Webb, 1991; Webb, Farivar, \& Mastergeorge, 2002). Yet, we still have much to learn about how to use cooperative learning within mathematics classrooms as a tool towards equity.

In this review, I will bring together research related to mathematics education and cooperative learning (focusing on the substantial overlap between the two, but drawing on other areas as needed) to discuss how teachers might assist students in cooperative groups to provide equitable opportunities to learn. As a preliminary to a discussion of how to make opportunities to learn accessible to all students, I present a sociocultural view of mathematics learning, and argue for the importance of providing students access to the means to construct deep mathematical ideas, and positive mathematical identities. I go on to review what we know about structuring equitable group work for mathematics learning, and present a set of open questions for further investigation. 
Equity in mathematics learning: Considering mathematical ideas and identities Current mathematics education scholarship with an equity focus tends to draw from theories of learning that can loosely be termed social, including situated/situative, sociocultural, and cultural-historical theories of learning (e.g., drawing from Cole, 1996; Lave \& Wenger, 1991; Rogoff, 1990, 2003; Saxe, 1991; Vygotsky, 1978, 1986; Wenger, 1998). These perspectives on learning focus on the primacy of the activity or practice as a unit of analysis and consider language to be a primary tool that structures people's participation in these practices (Lerman, 2001). When engaged in meaningful human activities, people make use of available resources as means to accomplish the goals that emerge (Saxe, 1999). The activity, the resources, the patterned interactions between people, and the emergent goals, are all an important part of the learning that takes place. Therefore, studies of learning should take into account the whole social ecology that forms the context for human activity. An ecological approach considers the development of an individual in relation to the "immediate environment, and the way in which this relation is mediated by forces emanating from more remote regions in the larger physical and social milieu" (Bronfenbrenner, 1979, p. 13).

In the context of cooperative group work and participation in mathematical practices, equity can be defined as a fair distribution of opportunities to learn, or opportunities to participate (Esmonde, 2007). ${ }^{1}$ From the outset, it should be said that by equity I do not mean equality, which focuses on strict quantitative measures (Secada, 1989). Instead, equity refers to some qualitative sense of fairness, much more open to debate. Deciding whether a particular situation is or is not equitable is also, in part, a political question, and one for which there may be little consensus. Differential 
achievement has to some extent been normalized in North American schools, and many students, teachers, and families expect that some students are 'smarter' than others and that smarter students should get better grades. This seemingly 'natural' order is called into question by visions of equity that push for less variability in achievement outcomes. Even more controversially, if one sees mathematics learning as a civil right that has been denied African Americans (Moses \& Cobb, 2001), one could argue that African American children should be taught even more mathematics than White children - it will be more necessary to their future success than it is to those who already hold privilege ((Woodson, 1933/1972) as discussed in (C. D. Lee, 2008)).

Defining equity as a fair distribution of opportunities to learn also invites debate around what constitutes an 'opportunity to learn.' The construct 'opportunities to learn' (OTL) has long been used in sociological approaches to understanding equity in education (Elliott, 1998). In this usage, OTL refers to "the overlap between what is contained in an achievement test and what is actually covered by a student's textbooks and teachers in preparation for the test” (McPartland \& Schneider, 1996, p. 67). Others have broadened their definitions of OTL to include "course content, instructional strategies, teachers' background, class size, students' readiness (initial achievement levels), and the availability of physical resources (such as books and equipment)" (Elliott, 1998, p. 225). The general argument underlying such research is that students should not be held accountable for material that they have had no opportunity to learn. This argument has prompted the rise of 'opportunity-to-learn standards' that focus on many of the technical and structural aspects of schooling (Porter, 1995), but ignore classroom talk and interaction (the 'immediate environment in which learning takes place') as well as 
broader factors such as class and racial differences in home and community practices (Dougherty, 1996).

Scholars who study opportunities to learn have argued that the persistent 'achievement gap' in mathematics education (and other content areas) should be reframed as an ‘opportunity gap' (Flores, 2007). Students of color, students living in poverty, students who have been identified as needing Special Education resources, and English Language Learners are more likely than their White, middle-class, Englishspeaking peers to be denied access to experienced teachers, challenging mathematics courses, and, within the classroom, high expectations from their teachers (Flores, 2007; Oakes, Joseph, \& Muir, 2003). While there are substantial across-school and acrossclassroom differences in opportunities to learn as indexed by these factors, in this paper I focus on how inequity can be constructed within a single classroom - within a single cooperative group.

Although opportunity-to-learn standards attempt to clarify what schools should do to provide adequate educational opportunities, these standards tend to be quite broad and are not always grounded in theories of learning so have little basis for analysing what happens at the micro-interactional level, in classrooms where learning is taking place (Tate, 1995). I therefore begin by laying out elements of a sociocultural theoretical framework for understanding OTL in cooperative groups, focusing on four main points: learning happens 1) through participation, 2) in relation to a social ecology, 3) through processes of identity development, and 4) through communicating about mathematical content. 
Learning and participation. Learning can be defined as a change in participation in a particular set of collective practices (Lave \& Wenger, 1991). This change comes about through adaptation to or adoption of a community's ways of speaking, acting, and interacting - although these community practices also change (Rogoff, 2003). In school, mathematics learning has come to be conceptualized as learning to participate in mathematical practices. That is, students learn to construct representations, make arguments, reason about mathematical objects, explain their thinking, construct proofs, and so on (Schoenfeld, 2002). Some practices that are central to academic mathematical communities (e.g., critiquing other people's arguments) may feel uncomfortable or difficult for some students, if these practices are not common, or have a very different meaning (e.g., taken as a personal attack) in other community practices (Enyedy \& Mukhopadhyay, 2007).

Although one may at first be a 'peripheral' participant, observing these practices without participating centrally, or having one's competent participation heavily supported by others, the goal is for learners to adopt more central participation without the teacher's direct help. ${ }^{2}$ Wenger (1998) used the term 'marginality' to describe a position that is kept peripheral to a community of practice. Peripheral participation in a community of practice may be necessary for a period of time, while one prepares for full and central participation. In examining mathematics classrooms, it is not enough to note that some students participate less centrally than others; rather, the question is whether students who are peripheral are supported in moving gradually to a more central position, or whether the participation is truly marginal, with peripheral students prevented from taking up more central forms of participation. In group work, equity in terms of 
participation is not simple to observe or analyse - rather than looking to see that all students participate in the same ways at all times, it is important to look to see whether all students' forms of participation allow them to move on a trajectory towards more central and competent participation in classroom practices.

Social ecologies of learning. No learning is 'decontextualised.' To understand a learning context, it is necessary to know the kinds of cultural forms available, the histories of the practice and of the participants, and the varied positions that people can take up within the practice. In educational research, notions of context have begun to move beyond the classroom walls, as a number of mathematics education researchers have begun to consider the relationship between a student's home/community and school practices (D. D. Anderson \& Gold, 2006; D. Baker, Street, \& Tomlin, 2006; Boaler, 2002). An ecological approach emphasizes all of these: cultural forms available, histories of the practice, the immediate local context, more distal societal structures, and considers how at any given moment, all of these are acting in relation to one another (Bronfenbrenner, 1979; Erickson, 2004).

For example, some have argued for a research focus on "how continuities and discontinuities between out-of-school and classroom practices play out in terms of access" (Cobb \& Hodge, 2002, p. 252). Classroom activities, including mathematical talk, do more than just convey mathematical ideas. Every moment of classroom interaction is also a part of the construction, challenging, and reification of students' social positions or identities, some of which are constructed primarily in the classroom, and some of which are related to broader communities in which students participate. 
Identity development and learning. Whether identity is conceptualized as a set of beliefs about oneself (Martin, 2000), as a subject position in relation to other people within a practice (Walshaw, 2005), or as a narrative that is told about oneself (McAdams \& Bowman, 2001; Sfard \& Prusak, 2005), one's identity changes within the context of a particular practice, as one becomes more adept at the practice (or as others become more adept!). While different conceptualizations of identity are valuable for different theoretical purposes, in this review I consider identity primarily as it is made manifest in social interaction, through the ways that people position themselves and are positioned by others (Davies \& Harré, 1990). (I will therefore use the terms 'identity,' 'identification,' 'subject position,' and 'positioning' somewhat interchangeably.) Positioning happens all the time, and in all contexts, through markers such as the language we speak, the way we dress, who we interact with and how, and so on (Holland, Lachiotte Jr., Skinner, \& Cain, 2001). Whereas the term 'identity' may carry the connotation of an enduring, static, essentialized self, positioning points to the ways in which one does not have 'an identity,' but rather inhabits or invokes multiple 'identities' or 'identifications.' These identities may shift in meaning or salience as one moves from one context to the next.

However, just because they are constructed in the moment, and not predictable in advance, does not mean that individuals have perfect freedom to construct their identities or subject positions in any way they choose. Collective practices, including group work within a mathematics classroom, make particular subject positions available to students. Or, to use a slightly different language, classroom collective practices are built around what Gee (1996) calls a Discourse, "a socially accepted association among ways of using language, of thinking, feeling, believing, valuing, and of acting" (p. 143). ${ }^{3}$ These 
Discourses can be used to "identify oneself as a member of a socially meaningful group or 'social network', or to signal (that one is playing) a socially meaningful 'role"” (p. $143)$.

Language, clothing, body positioning, and other aspects of Discourses have historically developed, and come with social significance. Specifically in mathematics, “classroom learning is not so much about the individual's acquisition of bytes of knowledge but is about learning how to behave appropriately, learning how to read the context of the lesson, and use the right kind of language (Solomon, 1998) and learning how to be perceived as a high ability pupil" (Black, 2004, p. 357). Adapting to these 'ways of being' may be easier for students from some social groups than for others. For example, in schools in which 'Standard English' is valued and students' home languages - whether they be different dialects of English, or other languages - are devalued, then adopting the school's valued Discourse may feel like a rejection of one's home community, undoubtedly a difficult and painful decision to make (J. Baker, 2002).

Up to this point, sociocultural and situated theories of learning have not been able to adequately deal with the complex ways that race, culture and power influence the nature of social life (and learning) (Hodge, 2006; Nasir \& Hand, 2006). Neither a view of equity in cooperative work that focuses solely on students' pre-existing socially constructed 'identities' (e.g., intersections of race, class, gender, sexuality, language communities, etc.) nor a view that ignores these social categories in favor of moment-tomoment acts of positioning, is completely satisfying. The first view ignores the shifting nature of group interaction, as students themselves work out a social order for the group, and the second view ignore the fact that these pre-existing social categories do influence 
the nature of classroom interaction, though not necessarily in predictable or simple ways (see, for example Boaler, 2002; Lubienski, 2007; Martin, 2006). In this paper, I will draw on research from both perspectives and work to bring them together. However, much more work remains to be done on this topic.

Communication and learning. In addition to looking broadly at the social ecology of the setting, and which subject positions are made available to the various students in the class or group, it is of course important to consider the nature of the content-related talk, writing, gestures, and so on. Mathematical communication should allow students to make sense of one another's mathematical ideas in ways that help them participate in discourse practices such as reasoning, argumentation, conjecture, proof, etc (Lerman, 2000).

Building on Vygotksy's $(1978,1986)$ seminal work on social interaction and learning, Wertsch (1984) emphasized the importance of intersubjectivity, a state in which two (or more) people have a shared meaning for a particular situation, and know that they share that meaning. As people make efforts to communicate about and solve emergent problems in collective practices, there must be a mutual bridging of ideas, rather than a simple transmission from one person to another (LeBlanc \& Bearison, 2004; Rogoff, 1990). In this paper, I consider intersubjectivity in a slightly weaker sense than Wertsch's, since there is no way for two people to fully know whether they have come to a shared meaning (Lerman, 2000; Schegloff, 1991). Despite this difficulty, in conversation people are constantly checking to see that they do have some basic shared meaning, and initiating conversational repairs when it becomes clear that they have been misunderstood (Schegloff, 1991). Intersubjectivity is not just a matter of agreement in a 
group - recent research in mathematics education have shown that students must develop some sense of intersubjectivity even to disagree with one another (Nathan, Eilam, \& Kim, 2007).

Intersubjectivity is of particular concern when considering cooperative learning in mathematics because student explanations play a central role in group work. If students are focused on their own mathematical explanation, rather than the hearer's understanding, then the cooperative learning process may be hampered (Ross, Haimes, \& Hogaboam-Gray, 1996). Further, considering intersubjectivity may shed some light on issues of equity in mathematics learning because of the cultural and social component of communication, as I describe below.

Breaches in intersubjectivity may occur around classroom processes, as when the teacher has a very different view of desired behavior or interactions than students do, or when students have different views from one another. For example, Ballenger (1999) discussed how, as a white middle-class teacher, she did not initially understand her Haitian pre-schoolers' interpretations of her classroom practices, nor did they understand hers. Lubienski discussed how her use of mathematics word problems was understood differently by her middle-class and her working-class students (2002). De Haan and Elbers (2005) present examples from intermediate mathematics classes in the Netherlands, in which Dutch-born students predominantly had one set of normative practices that they considered appropriate for group work - "helping" without directly "telling" or giving the answer away - while the immigrant students had another set of normative practices - "telling" without withholding information from one another. These three cases provided examples of breaches in intersubjectivity related to appropriate ways 
of speaking and interacting within a community. While breaches in intersubectivity may occur between even the closest of friends or family members, these three examples highlight that in some cases, these breaches may occur because participants are from different cultural communities, and draw on different repertoires of practice (K. D. Gutierrez \& Rogoff, 2003) for making sense of their interactions.

These sociocultural and situated theories of learning, with an emphasis on identity development as well as the role of talk in mathematical content learning, will serve as a guide for the remainder of this paper. The goal of this review is to understand how various classroom social ecologies make space for students to participate in mathematical discourse practices and to be positioned as competent. Throughout, I will revisit the question of fairness and equity as I review empirical research on cooperative learning in mathematics, and discuss what is known about structuring equitable opportunities to learn, as well as open questions that deserve attention from the field.

$$
\text { Interaction, mathematics learning, and equity }
$$

Educational research on the use of cooperative groups has tried to explain why some groups and some activities are more effective than others. A natural first place to look is at the kinds of interactions that groups engage in. A tacit assumption in much of this research is that the classroom context affects the way the group members interact with one another, and that these interactions lead to learning. This connection is illustrated in Figure 1. 
Figure 1: Context, interaction, and learning in cooperative groups

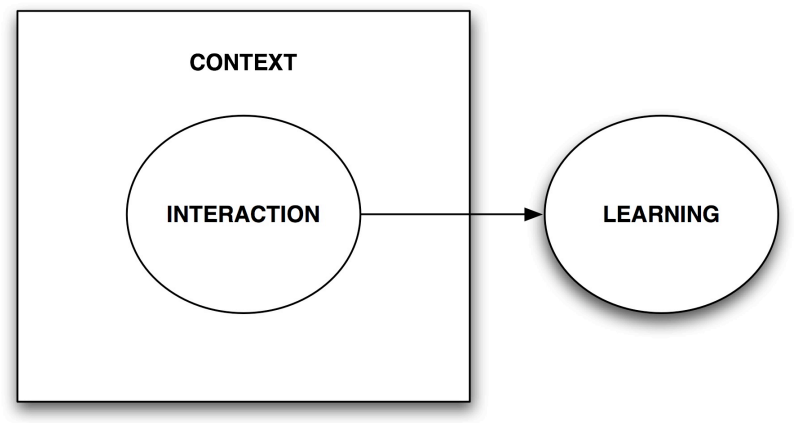

The square box to the left represents a number of factors that can collectively be described as context. I am purposely using the vague term 'context' at this point because different researchers and different paradigms of research have focused on different aspects of the 'surround' of group work. For the purposes of this review, I use context to refer to the aspects of the cooperative learning situation that the teacher could affect or modify. These include the type of task, the types of rewards, the resources available, etc. 'Interaction' rests inside 'context' to represent the idea that the appropriate unit of analysis is the person-in-context. The link between the two ovals for interaction and learning represents the position that from sociocultural perspectives, participation and learning are tightly connected.

In addition to highlighting the underlying assumptions of much of the research on cooperative learning, Figure 1 serves as an organizer for this review. The bulk of research on cooperative learning has either focused on how various group interactions support learning, or on how classroom contexts support learning. Very few studies have provided rich descriptions of the context, student interactions, and investigated learning outcomes as well. As a result, in this section I will focus first on research that analyses the link(s) between various kinds of group interactions and mathematical learning (in terms of 
positioning and mathematical content). That discussion will lead to the following section, in which I use research about interaction and learning to discuss how cooperative contexts can be structured to support equitable opportunities to learn.

Interaction and learning: focus on ideas

I begin by considering empirical studies that focus on how group interactions lead to various learning outcomes. These studies are the empirical counterpart to the earlier theoretical discussion about the link between social interaction and learning. On the question of which kinds of group interactions lead to greater learning gains, the answers have been mixed. Some results include the following.

Quantity of interaction does not matter for individual success. In one experimental study in which groups solved word puzzles, researchers found that just observing a video of groups interacting was enough to help individuals be more successful - they didn't have to interact with others directly (Olivera \& Straus, 2004). (Although this study does not concern learning of mathematical concepts, I include it here because of the contrast with findings of other studies.)

Quantity of interaction matters for individual success. A number of studies in mathematics and other content areas have found that any type of on-task talk can help one to succeed (Bianchini, 1999; Cohen \& Lotan, 1997). These studies are based on Complex Instruction (CI), an instructional paradigm that includes collaborative work on ill-structured problems, and specific kinds of teacher interventions to encourage participation of all students. Studies taking the CI approach have repeatedly shown that rates of on-task participation are positively correlated with achievement gains. Some studies specific to mathematics have demonstrated that the CI approach can be fruitfully 
adapted to mathematics, though these studies did not include analyses linking student interaction rates with achievement (Boaler, In press; Boaler et al., 2006; Boaler \& Staples, In press).

Quality, not quantity of group interaction matters for individual success. An equally impressive number of studies in mathematics have shown that rates of on-task participation are not always positively correlated with achievement gains (Webb, 1991; Webb \& Palincsar, 1996). Instead, specific kinds of interaction - sometimes referred to as 'processes' - may be necessary to support learning. Some specific processes that have been associated with increased achievement include asking questions (A. King, 1991), discussing problem-solving strategies (Chizhik, 2001), observing someone else's problem-solving strategies (Azmitia, 1988), teaching a peer (Schwartz \& Okita, Submitted for publication), resolving a disagreement or conflict (Buchs, Butera, Mugny, \& Darnon, 2004; Johnson, Johnson, \& Smith, 2000) and explaining one's thinking (Fawcett \& Garton, 2005; Nattiv, 1994; Webb, 1991). Asking questions without receiving answers has been shown to have a negative effect on achievement (Webb \& Mastergeorge, 2003).

Group interactions are successful chiefly because they prepare students for future learning. Several studies in science education have argued that the key benefit of cooperative learning may be that it lays the groundwork for future learning from lectures, worked examples, or other forms of more didactic instruction (Howe, McWilliam, \& Cross, 2005; Howe, Tolmie, \& Rodgers, 1992; Schwartz \& Martin, 2004). These studies suggest that cooperative learning works best when embedded in a larger pedagogical strategy that includes lectures, textbooks, or other authoritative learning resources. They 
reinforce the need to elaborate on the role of cooperative learning in the social ecology of the classroom, and its relationship to other classroom practices and tasks.

Joint attention and taking up correct ideas are what matters for group success. In a study of high-achieving boys jointly solving complex mathematical tasks, Brigid Barron $(2000,2003)$ found that group variation in achievement could not be explained by variation in the individual achievement levels of group members. Differences in group achievement were a result of the variation in social organization, rather than in varying access to the knowledge required to solve the problems. Successful groups were more likely to take up correct ideas, and to maintain joint attention, through attending to one another's behavior, sharing group artifacts, and responding directly to one another's ideas. In the less successful groups, students were more likely to talk past or ignore one another, and to hoard the group's resources. These findings demonstrate the importance of attending to between-person processes of interaction, which cannot be reduced to counts of individual behaviors (Sawyer \& Berson, 2004).

The varied empirical findings listed above seem to support the general theoretical proposition that gaining intersubjectivity helps a group develop mathematical reasoning and practices. For example, the finding that having one's questions answered by the group tends to help one learn, while having one's questions ignored does not, supports the idea that comparing ideas and coming to know the mathematical practices of other group members (intersubjectivity) can help students develop their understanding of mathematical concepts. Further, the 'joint attention' that Barron emphasized is a key component to intersubjectivity. The research findings are therefore in line with 
expectations derived from theoretical accounts of learning. The implication is that groups where students work towards intersubjectivity with their peers are more equitable.

However, there are some direct contradictions within the findings that require explanation; one set of studies says that any type of interaction should lead to learning, while another says that only specific kinds of interactions will do so. Cohen (1994) argued that the seeming contradiction rests in the social and cognitive demands of the task. She asserts that success on complex, ill-structured tasks requires different group interactions than success on more routine or procedural tasks. For example, in illstructured or complex problems, students can benefit from hearing several different solutions (all of which may be correct) and arriving at intersubjectivity by considering how the solutions are the same or different (Yackel, Cobb, \& Wood, 1999). On rote or procedural tasks, students might be encouraged to strictly follow a procedure without considering alternatives, so a different set of interactions might be appropriate - some even argue that group work is inappropriate for such tasks (Phelps \& Damon, 1989). In the set of studies cited above, there was no single way to define a successful learning experience. Since the studies had different measures for success, it makes sense that different sets of interactional behaviors would lead to different successful outcomes (Mercier, 2008). More work is needed to identify which kinds of classroom ecologies support which kinds of learning interactions and outcomes, as well as which kinds of interactions lead to which kinds of success.

A second issue to raise with this set of studies is that they emphasize the importance of talk, while downplaying the possibility that children can learn from observation and listening (Hatano \& Inagaki, 1991). Quantitative studies that count turns 
at talk, and qualitative studies that rely on audio-recordings or transcripts, cannot distinguish whether silent students are engaged or disengaged. While I would argue that silent students miss the opportunity to bring the group to an intersubjective understanding, it is important to study the successful learning strategies of silent students. Returning to the question of equity, several of the studies cited above noted trends about who had access to valued forms of participation. The studies in CI classrooms reported that students who they call 'high-status' do most of the talking, and learn more than other group members. Webb (1984) and Mulryan $(1992,1995)$ found that in their samples, boys tended to initiate discussions more than girls did, and high-achieving students controlled group sessions while low-achieving students behaved more passively (Mulryan, 1994; Webb, 1989). These findings demonstrate that if analyses of group interactions do not attend to positioning and identification, they cannot fully address equity issues in mathematical cooperative work.

Interaction and learning: focus on identity

A sociocultural lens on learning pushes us as researchers to consider interactions more broadly than just the content that is conveyed through talk, gesture, observation, etc. As people interact within collective practices, their interactions serve to position themselves and others as specific kinds of people, and these positionings have affordances and constraints for their participation (Gee, 2000). Since mathematics education has traditionally been dominated by cognitive psychology, a discursive or identity-based approach to understanding learning has not been well-represented in the research literature until recently (Kilpatrick, 1992; Lerman, 2001). While a full review of 
this approach to mathematics education research is not feasible here, I will sketch recent developments as they relate to mathematical group work.

It has been repeatedly shown that in mathematics, as in other subject areas, students with more experience and identification with mainstream or dominant practices tend to be privileged in classroom discourse (C. D. Lee, in preparation; Lubienski, 2002; Nasir, Rosebery, Warren, \& Lee, 2006). In other words, students who come to school already speaking the school Discourse(s), and behaving as teachers expect, are provided more opportunities to learn than their peers. These privileged students are often white, middle-class students whose first language is English. Often, those who do not embody these privileged ideals are positioned as deficient and difficult to teach, and report that their teachers do not seem to care whether they learn mathematics (Walker, 2006). In addition, while a gendered achievement gap has greatly diminished in K-12 schools (Tate, 1997), many students still report that mathematics classrooms are masculinedominated spaces (Mendick, 2005; Rodd \& Bartholomew, 2006).

One hallmark of reform mathematics classrooms is that teachers try to build on their students' prior understandings and experiences, by allowing students to invent strategies for solving problems, and by using familiar contexts in which to pose problems (NCTM, 2000). These strategies can also have the effect of positioning students' home and community practices as valuable resources for learning (Bishop, 2001). Many successful urban students of color report that their success comes through their own agency and effort, but relying on informal collaboration and support with neighbors, family, and friends from their communities (Ainsworth-Darnell \& Downey, 1998; Martin, 2000; Walker, 2006). There have been several innovative and successful 
classroom interventions that have attempted to formalize such collaborations and support systems by bringing them into the classroom, and building on students' home and cultural community practices (Civil, 2007; Gonzalez, Andrade, Civil, \& Moll, 2001; Gutiérrez, 2002; K. D. Gutierrez \& Rogoff, 2003; Nasir, Rosebery, Warren, \& Lee, 2006).

However, these strategies may be unsuccessful if the teacher does not understand the strategies that marginalized students bring (Ball, 2002), or lacks familiarity with students' communities and so cannot use these contexts. In addition, teachers may not recognize students' competence in mathematical discourse practices if students are not fluent speakers of (academic, mathematical) English (Moschkovich, 2002).

The foregoing discussion shows that students' positional identities - and the way these identities are reified, produced and reproduced in classroom contexts - influence their experiences in mathematics classrooms. A second consideration with respect to identities and mathematical learning is the 'identity work' that non-mainstream students must do in order to be perceived as successful mathematics students. Mathematics reform efforts are based on the assumption that students should form positive mathematical identities as knowers and doers of mathematics. For students of color, girls, working class students, and others who are not always positioned as mathematically competent, considerable work must be done to merge their positive academic identifications with their identifications with other social communities, or to fluently participate in these multiple and sometimes very different Discourses (Buxton, 2003; Lucey, Melody, \& Walkerdine, 2003; Martin, 2000).

There are at least two questions of interest in considering how identity development relates to mathematical learning in cooperative groups. The first is a 
question of gatekeeping: does a person's or group's identity influence the nature of mathematical content learning available to them? I will discuss several approaches to answering this question: from considerations of classroom status to positioning, and considering student characteristics such as race, gender, and prior or perceived achievement levels.

The second question of interest concerns identity development itself: paralleling the earlier discussion about how group interactions lead to content learning, I examine how interactions (in which social ecologies) allow for the development of positive mathematical and social identities. Proponents of cooperative group work often argue that working in groups helps students take on classroom authority by becoming less dependent on the teacher (see, for example, many of the chapters in Sharan, 1999). The problem is that these identity-related shifts are not often documented or studied. There is, however, a small body of work that considers how mathematics students develop competent positional identities through specific cooperative pedagogies, and I will discuss these further below.

\section{How identities influence mathematics learning in group work}

In this section, I consider research related to how students' social identities influence the nature of learning in cooperative group work. There have been a number of different approaches to addressing this question. I should note at the outset that I do not address research that attempts to answer the question 'is cooperative learning good for boys/girls/students of color/English language learners' and so on. As Walshaw (2005) points out, some have argued that girls inherently are more cooperative than boys and should fare better with group work (Becker, 1995). Similarly, some have argued that 
African American students' cultural learning styles are suited to joint sense-making activities in cooperative-based mathematics classes (Berry, 2003). One meta-analysis of several studies of cooperative learning in elementary contexts found that 'peer-assisted learning' was most effective with young, urban, low-income, 'minority' students (Rohrbeck, Ginsburg-Block, Fantuzzo, \& Miller, 2003). These generalizations are controversial, though, and the literature contains many counter-examples (see, e.g., Chizhik, 2001; Mulryan, 1995). Rather than focusing on this type of research, that usually treats cooperative learning as a black box and does not investigate the nature of group interactions, others have argued that it is more helpful to examine specifically what about social interactions in mathematics might support learning for these students, rather than assuming it is 'in their nature' to enjoy them or benefit from them (Lopez-Reyna, 1997).

Therefore, I consider research in this section that focuses on how socially constructed identities play out in contexts of collaboration. The first research paradigm that I consider focuses on group composition, in an effort to outline how students can be most equitably grouped together. Features of group composition that have been extensively studied have included gender (e.g., single-gender group vs. mixed gender groups (Mulryan, 1992)) and prior achievement (e.g., investigating the optimal mix of 'high,' 'mid' and 'low' achieving students). Race is less frequently studied. These studies of group composition are difficult to interpret without more information about the classroom social ecologies that frame group activity. Consider the following set of findings. 
In terms of gender composition, a typical finding was that groups with a gender balance between boys and girls tended to achieve at higher rates than groups that were single-gender or that were unbalanced (e.g., one girl and three boys). Again, the achievement data was found to be a result of the interaction styles of the groups, in which girls were marginalized (even in groups where they were the majority) (Webb, 1984). Despite this finding, it is clear from other research that it is possible for girls to work out relatively comfortable ways to participate and learn in mathematics classes, from kindergarten through graduate school (Rodd \& Bartholomew, 2006). That being said, in contexts where mathematical success is associated with masculinity, girls must either construct ways to be mathematically successful while also maintaining conventional femininity (Mendick, 2005), or construct more masculine identifications.

Studies of friendship are similarly inconclusive. Many students prefer to work with friends, and may be more likely to disagree and to work through disagreements (Azmitia \& Montgomery, 1993; Strough, Berg, \& Meegan, 2001; Zajac \& Hartup, 1997). However, the students sometimes report that they prefer to work with acquaintances or strangers, and not close friends (Mitchell, Reilly, Bramwell, Solnosky, \& Lilly, 2004; Walker, 2006). To some degree, the optimal group composition (friends or non-friends) probably depends on the task and the people involved.

Research that compares different grouping schemes based on prior achievement has also produced a number of contradictory findings. One study, as reported in Webb's (1984) meta-analysis of research on group composition, found that groups of four highachieving students often had relatively low levels of participation, and therefore lower achievement than they might have had in other types of groups. In a later study, also 
published by Webb and colleagues (Webb, Nemer, \& Zuniga, 2002), this finding was called into question, as she reported that high-achievers tended to do well when grouped together homogeneously, and sometimes did well when grouped with low-achievers. Low-achievers uniformly had higher achievement when grouped with high achievers. A third study of high-achievers in group work found that they had similar achievement gains regardless of whether they worked with high- or low-achieving partners (Carter, Jones, \& Rua, 2003).

Despite the conflicting findings, these studies demonstrate that any configuration of groups will benefit some students more than others, which raises a question regarding 'fairness.' Would it be fair to group high achievers together, knowing that this would support their learning the best? Or, would it be fair to group them with low-achieving students, in an effort to support the low-achievers and perhaps narrow gaps in achievement? On the other hand, if low-achievers are marginalized in group work (as in Baxter, Woodward, \& Olson, 2001; L. H. King, 1993), perhaps they should be grouped together, to provide more opportunities to engage in mathematical discussion, rather than just copying the work of their high-achieving peers.

The issue is complicated further by the fact that in many school districts, lowachieving students are disproportionately underserved working-class and poor students of color (J. Lee, 2002). As a thought experiment, imagine a classroom in which the white students were higher-achieving than the students of color. Would an anti-racist approach to teaching group students of color together for solidarity, or divide these students up so that they would be taught by their white peers? An appropriate course of action, to best 
support the learning of 'all students,' is as much political as empirical, and will depend on one's values for equity in education.

Setting aside the difficulty in determining which kinds of grouping might be more equitable, a second difficulty in interpretation arises from studies in this paradigm. Most research in this area does not discuss the social ecology of the learning environment. It is therefore difficult to understand whether the findings about optimal group composition would hold across a variety of cooperative learning settings. These studies additionally often take the social categories (e.g., race, gender) for granted, and do not consider how these positions are constructed in interaction. Gender, race, socioeconomic status and so on are always produced and reproduced locally, so local variations can affect the impact of these social categories on student interactions and identities (Erickson, 2004). Therefore these studies cannot support the conclusion that, for example, 'mixed gender groups are better.' More research is needed to understand how various cooperative pedagogies influence group interaction, and how and when these interactions influence social categories such as race, gender etc. In other words, the classroom context and activities should be considered an independent variable, and the local construction of race, gender, friendship, and other categories, dependent.

A second research paradigm that has considered how social identities influence learning in interaction has tried to generalize about these identity-related constructs, and focuses instead on classroom status. Arising out of a sociological tradition, this type of research focuses on how student characteristics (including socially constructed categories like race, gender, class, as well as variables like perceived ability and popularity) may affect how students are perceived by their group and how students interact within the 
group (Berger, Cohen, \& Zelditch, 1972; Bianchini, 1999; Boykin, 1986; Chizhik, 2001;

Cohen, 1982; de Abreu, 1995; Dembo \& McAuliffe, 1987; McAuliffe \& Dembo, 1994).

The idea is that group interactions are influenced by members' status characteristics characteristics of a person that are "differentially evaluated in terms of honor, esteem, or desirability" (Humphreys \& Berger, 1981, p. 955) such as race, gender, educational attainment, and so on.

This area of research is built upon expectation states theory (Berger, Cohen, \& Zelditch, 1972), a sociological theory of status that models how individuals construct expectations for one another's competence in activity. They argue, and demonstrate empirically, that in many situations, a group will act as if higher status people are more competent than lower status people. Expectation states theory further argues that people tend to 'add up' status characteristics to determine who has the highest status (Shelly \& Troyer, 2001); as a corollary, they argue that increasing the number of potentially relevant status characteristics can act to mitigate the influence of any one characteristic.

Classrooms are different from experimental studies in a number of significant ways, not the least of which is that students in a cooperative classroom often work with peers every day. Therefore, some have argued that status characteristics that are dominant in laboratory experiments with participants who have never met (e.g., race, gender, position of authority as in (Cohen, 1982)), are less important in the classroom. In fact, Cohen, Lotan and their colleagues have argued that a combination of 'popularity' (roughly, number of friends) and 'perceived ability' (the number of people who name one as smart) - are the most important status characteristics in a classroom (e.g., Cohen \& Lotan, 1997). In an impressive number of studies, including but not limited to 
mathematics classrooms, it has been shown that high status students tend to dominate classroom discussions, and ultimately learn more through their group interactions (see, e.g., Bianchini, 1997, 1999; Cohen \& Lotan, 1997; Cohen, Lotan, Scarloss, \& Arellano, 1999; Lotan, 2003; Perrenet \& Terwel, 1997).

These studies call into question the practice of heterogeneous grouping. The dominance of high-status group members may seriously undercut the goal for low-status students to also develop self-reliance, authority, and positional identities within mathematical Discourses. Teachers will have to confront this issue in their pedagogical strategies, and make difficult decisions about who should be advantaged in their classes.

While the work on the influence of status characteristics is promising and has been successfully replicated in a variety of classrooms, there are several problems with drawing too heavily on status or expectation states research. One underlying assumption of expectation states theory is that participants all believe that some group members are more capable than others. There are alternative explanations. For example, if some type of stereotype threat had been activated, then African American students or girls might participate less in mathematical discussions, not because they believe themselves to be less competent, but because they expect to be evaluated in ways that reinforce undesirable stereotypes (Steele, Spencer, \& Aronson, 2002). We should be wary of assertions that all participants in a situation are acting on the same beliefs.

Further, there is little empirical support for the notion that one can 'add up' status characteristics. In cooperative work, groups must deal simultaneously with conceptual demands, task demands (i.e., how to satisfy the teacher's requirements for an assignment), and social demands (C. W. Anderson, Holland, \& Palincsar, 1997; Barwell, 
2005). There may be more than one status continuum at play, with varying effects on the group's interactions (Esmonde \& Langer-Osuna, 2007).

Finally, although several studies have found that popularity and perceived ability are the most important factors determining classroom status, and that race and gender do not add explanatory value to their models (Bianchini, 1997; Cohen \& Lotan, 1997), that does not mean that race and gender are not connected to classroom assessments of status. Mathematics learning is a racialized experience (Martin, 2006), and students' assessments of popularity and perceived ability can be associated with race, gender, class, etc. A critical unresolved question of status research is, how and why do status hierarchies form in the classroom, and what are the factors that help some students be positioned as more competent than others?

How identities develop through group work

In addition to considering how identities influence group interactions, it is also important to consider how group interactions influence positional identities. When working together in some cooperative contexts, group members may over time develop relatively static roles within the group (Hogan, 1999). This process is not always conflictfree, especially when students of different backgrounds hold different values about how to structure the group's joint work practices (de Haan \& Elbers, 2005; R. Stevens, 2000).

Because development of positioning and identity have been understudied with respect to mathematical cooperative learning, there is little written about how different kinds of classroom environments or group tasks allow for different kinds of positioning. One particularly interesting case has been the adaptation of Complex Instruction to secondary mathematics classes (Boaler, In press; Boaler et al., 2006; Boaler \& Staples, In 
press). These studies indicate that in a California high school using the CI approach, students gradually changed their ideas about who was 'good at math.' In a comparative sample at a nearby high school, students had no trouble dividing their peers into categories (that is, positioning them): those who were good at math, and those who were not. By contrast, students who used Complex Instruction positioned more of their peers as 'good at math,' and emphasized that there are a number of different ways to be good at mathematics. These broad perspectives on mathematical competence increased the number of positive positional identities available to students. These broadened notions of competence were accompanied by achievement gains that were much larger than those in schools with more traditional curricula.

The field needs more research into positional identities, how they emerge in varied cooperative learning contexts, and how these positions are related to the classroom's social ecology (Erickson, 2004). Research on Complex Instruction has managed to combine attention to positioning as well as to interaction around mathematical ideas, to show that high status students tend to talk more than their peers and consequently learn more mathematics. It will be important to continue research in this vein as a way to make connections between classroom social ecologies, the interactions that they foster, and the kinds of positional identities that are made available to students.

Relevant research questions include: How are positioning and group interaction styles related, and what are the implications for equity? In what contexts are students who are positioned as peripheral offered opportunities to explain their thinking, get detailed answers to questions, and so on? And how are both positioning and interaction related to 
broader social categories like race, gender, socioeconomic status, language and Discourse communities and so on?

Summarizing research on interaction, mathematics learning, and equity

Evidently, there are still many open questions that would inform the research community's understanding of how group interactions in mathematics classes lead to the development of mathematical ideas and identities. The foregoing discussion has emphasized the importance of considering both ideas and identities together when examining cooperative group interactions. As reported above, a series of studies has highlighted that some ways of interacting are more likely to lead to meaningful mathematical learning than others. Explaining one's thinking, getting a detailed response to one's questions, maintaining joint attention, and guiding a group's problem-solving process, all tend to support mathematical learning. However, in many cases not all group members are able to engage in these valued interactions, perhaps because of their positions or identifications within the group.

To work towards a fair distribution of opportunities to learn, teachers must consider not only the kinds of valued interactions that they want students to engage in, but also how students are positioned as mathematics learners, and students' identifications with mathematical Discourses. Students' positional identities, perhaps especially with respect to their mathematical competence, influence the way they interact with their peers. In diverse classrooms, students who are considered low-achieving by their teachers and peers, girls, working-class students, and students of color, may be marginalized and prevented from engaging in meaningful sense-making discussions with their groups. A critical question for any educator to face is how best to support the 
learning of all students through group work, when providing opportunities for some students may become obstacles for others.

In some classroom contexts, students who are positioned as more competent than others guide the group's work, while others wait to be told what to do (Esmonde, Manuscript submitted for review). The group focuses on achieving intersubjectivity with the 'expert' student, rather than putting all their ideas together and building on everyone's prior understanding. In other contexts, teachers have been able to equalize differences between students, allowing for more equitable participation in group discussions and mathematical learning. In the next section, I consider research that focuses on how contexts shape group interactions (or in some cases, how contexts shape achievement) to provide more equitable opportunities to learn for their students.

$$
\text { Context, mathematics learning, and equity }
$$

Teachers designing cooperative activities for their classrooms can structure these activities in many ways. It is important to consider context (or, the social ecology of classroom learning) because otherwise, there is a risk of blaming students who are disadvantaged by group work. The role of the teacher in structuring opportunities to learn during group work is critical (Yackel, Cobb, \& Wood, 1991), and in this section I discuss how to structure mathematics cooperative learning to minimize inequity. There are several dimensions of classroom context that have been extensively studied. Figure 2 opens up the box labeled 'Context' in Figure 1 and lists several of these dimensions: content of the group task; status; group composition; training, scripts and roles; and assessments and rewards. Each of these factors influences both the ideas that are at play 
in group interaction and the positional identities that are made available to group

members.

Figure 2: Contextual factors influencing group interaction

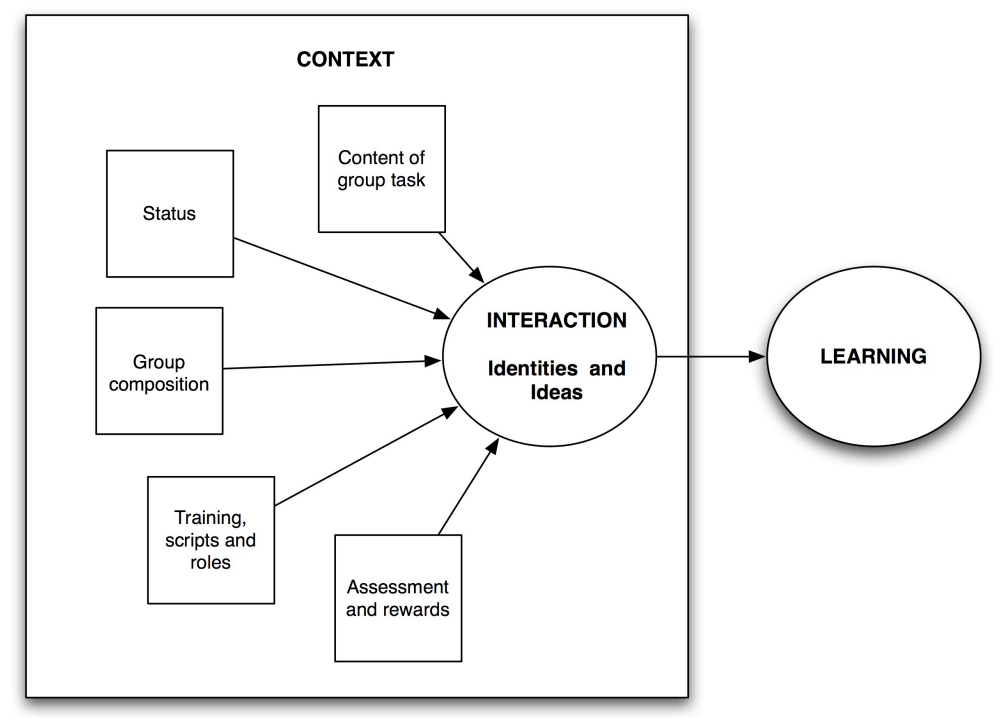

I have already referred to several techniques in the foregoing discussion, including structuring group composition so that students interact with one another productively and so that each student is in a group that will help them to learn. I will not repeat the discussion of these techniques here.

Eliminating status differentials to promote equity

There are two status interventions recommended by the CI research community (Bianchini, 1997, 1999; Cohen \& Goodlad, 1994; Cohen \& Lotan, 1997; Lotan, 2003). Both are based on expectation states theory, and the idea that if multiple status characteristics are in play, then the effect of any single characteristic will be diminished.

The first intervention is called the 'multiple ability treatment.' CI tasks are complex, often ill-structured tasks (that is, tasks with no clear solution strategy and sometimes, no 'correct' answer). The multiple ability treatment consists of publicly 
stating that there are many different skills required for success on the task, and that no one student has all of these skills, but each student has at least one. This emphasizes that all students in the group are necessary for success. In addition, researchers recommend that teachers explicitly describe some of the necessary skills. This will help students to see that competence is multi-faceted, and that no one student can accomplish the tasks alone.

There is evidence that in classrooms with broadened notions of competence, more students may find ways to participate in meaningful ways. In a compelling example from a high school mathematics class, several students in a group distinguished between 'understanding' and 'being good at explaining' (Esmonde, Manuscript submitted for review). Making this distinction allowed some students to contribute to the discussion, saying that they understood how to solve a problem, but were struggling to explain. These students were positioned as both competent and struggling, and were given opportunities to try to explain the mathematical ideas that they admitted were confusing to them.

The multiple abilities treatment intervention may be difficult to employ with a more traditional mathematics curriculum, one that emphasizes mathematical procedures and skills and where students may not be convinced that multiple abilities are necessary for success. It may also be difficult to convince students with a traditional mathematics background that mathematical competence involves more than speed and calculation. Changing students' positioning and beliefs about mathematics and smartness may take time and persistence on the part of teachers (Boaler \& Staples, In press). 
The second CI intervention is called 'assigning competence' and is used as the teacher circulates around the classroom, observing group interactions. When a teacher observes that a particular student is being marginalized, but has an important contribution to make, the teacher publicly positions that student as competent, and explicitly names the academic contribution they make to the group. It is important that the teacher name an academic contribution (e.g., "your idea is really important and your group should think about that"), rather than simply a social or behavioral one (e.g., "you're sitting nice and quietly") to encourage other students to recognize the marginalized student's competence. The central participation of lower-status students in a group actually benefits the whole group, who then have the opportunity to compare identities, correct errors, and come to a deeper understanding of mathematical concepts (Webb, Nemer, \& Zuniga, 2002).

This intervention may be difficult to carry out if teachers do not spend enough time observing their students, or if teachers struggle to recognize mathematical competencies in marginalized students. Further, this intervention depends on a student attempting to make a contribution, being denied by groupmates, and being recognized by the teacher. If a marginalized student refrained from contributing to the mathematical task, the teacher would not be able to employ this intervention. What may be needed, instead of or in addition to this intervention, are techniques for reformulating student interactions as on-task, competent, and mathematical rather than oppositional and off-task (Hand, under review). 
Using roles, scripts and training to promote equity

Another technique, used in Complex Instruction but also used more broadly, is to assign students particular roles in group work. These roles may be procedural (e.g. materials manager, recorder), cognitive (e.g., questioner, summarizer), or interpersonal (e.g., vibe-watcher, mediator). Assigning cognitive or sociocognitive roles to students helps to make explicit the teacher's goals for the group's mathematical talk. For example, when students in the 'audience' of a presentation are given explicit roles (that include asking questions, making sure the presenters have given an accurate model, etc), they may begin to view listening to a presentation as a time to actively participate, rather than waiting for the teacher to make an assessment (Herrenkohl, Palincsar, DeWater, \& Kawasaki, 1999).

In reciprocal peer tutoring (Fantuzzo, King, \& Heller, 1992), Scripted Cooperation (O'Donnell et al., 1990), ASK to THINK-TEL WHY (A. King, 1997), and reciprocal teaching (Brown \& Palincsar, 1989) students take turns explaining. While their peer explains, the listener's role varies. They may be asked to check for mistakes, or to ask probing questions. These roles provide all students the opportunity to contribute to the group's mathematical discussion, preventing the discussion from being dominated by a few.

Some procedures for assigning roles are designed to position all students as competent and necessary for group success. In jigsaw activities, for example, each student in a group has the opportunity to become an expert on a topic that the other group members know nothing about (Aronson \& Bridgeman, 1979; Clarke, 1994). Each student is then responsible for helping their peers learn about their topic; this builds in 
interdependence between students, because they need one another in order to learn. It also helps to position each student as 'smart' or as an expert in some way.

In Complex Instruction, procedural roles are assigned to students in an effort to both offload some of the managerial responsibilities from the teacher onto students, and to help offset some of the status differentials in the group (Bianchini, 1999). Bianchini recommends that roles should rotate within the group, but that low-status students should be given relatively high-status roles early on. She also urges teachers to monitor groups to make sure these low-status students are allowed to fulfill their roles.

When done well, assigned roles may help students to be positioned as positive contributors to the group process. However, students do not always enact the roles as the teacher would like (Bianchini, 1999), or adopt the desired cooperative behaviors (C. W. Anderson, Holland, \& Palincsar, 1997; Ross, Haimes, \& Hogaboam-Gray, 1996), and so constant monitoring, reinforcement, and encouragement may be required. Especially if students are accustomed to working individually, or competing for scant resources (grades, positive feedback) in the classroom, they will need assistance in learning how to support one another's learning (Johnson \& Johnson, 1991).

An alternative to roles and scripts is to teach effective cooperative learning techniques before beginning group work (see, e.g., Farivar \& Webb, 1994; Gillies \& Ashman, 1998). This approach has had mixed results. Some have found that training may have little effect (Ross, Haimes, \& Hogaboam-Gray, 1996), whereas others have shown that it may increase student achievement in cooperative activities (Ashman \& Gillies, 1997; Kelly, 2002; A. King, 1991, 1994). Ross's qualitative analysis of the group training process (Ross, 1995) demonstrated that while initial training may be valuable, it should 
be coupled with an ongoing process of feedback and reflection to help students improve their cooperative interactions. Finally, one study found that training had a greater effect on the participation and achievement of African American and Latino/a students than it did for White American students (Webb \& Farivar, 1994). More in-depth qualitative studies are needed to determine what type of training or education might help promote helping behaviors, and in which classroom contexts, for which students.

Training, roles and scripts, can each be seen as moves towards equity because they provide scaffolding for all students to participate in the valued discourse practices of academic mathematics, and to support competent positional identities for all group members. By using these techniques, teachers make their expectations explicit, a move associated with culturally responsive classroom management (Weinstein, Curran, \& Tomlinson-Clarke, 2003).

\section{Designing mathematical content that supports equity}

Mathematics pedagogies are influenced by the teacher's and the students' beliefs about what mathematics is, how it should be taught, and how it is best learned. Traditional skill-oriented mathematical tasks may encourage relatively procedural interactions between students, whereas more open-ended mathematical tasks may open up more possibilities for meaningful engagement in the group. In research on cooperative learning in mathematics, examples of cooperative tasks have ranged from basic mathematics computations (Fantuzzo, King, \& Heller, 1992), to word problems with fairly procedural solutions (Webb, Farivar, \& Mastergeorge, 2002), to open-ended tasks (Chizhik, 2001). There is often little discussion of how the task itself influences the findings (though Chizhik's work is a notable exception). 
Some of the early studies of cooperative learning used mainly procedural arithmetic tasks, and seemed to make the "tacit assumption... that knowledge consists of facts and procedures to be mastered, and that more knowledgeable children can serve to help less knowledgeable children master the facts and procedures" (Saxe, Gearhart, Note, \& Paduano, 1993, p. 117). By contrast, in mathematics as in other subject areas, many have argued that students are best served by solving more ill-structured or complex tasks (Cohen, 1994; Cohen \& Lotan, 1997; Cohen, Lotan, Scarloss, \& Arellano, 1999; Damon, 1984).

In the mathematics education research community, there is a growing consensus that students should learn mathematical procedures and algorithms, but only as a part of their mathematical education that includes deep conceptual understanding as well (Schoenfeld, 2002). Tasks that allow for multiple entry points, multiple strategies or solution paths, and even multiple correct answers, might allow all students in a cooperative group to engage with the mathematics, and to be able to participate in meaningful ways - explaining their thinking, asking specific questions, making connections between different strategies (Yackel, Cobb, \& Wood, 1991).

The influence of the task on group interaction was investigated in a carefullydesigned study that investigated participation and learning in two mathematical task conditions: an open-ended problem with more than one correct answer, and a problem with only one correct answer (Chizhik, 2001). In a task that had a clear procedure and one correct solution, many groups structured work practices in which one student would take the lead and tell the others how to solve the problem. There was little general discussion, and very few group members had the opportunity to contribute. By contrast, 
in the more ill-structured task, the group jointly determined how to structure and then solve their problem. In these groups, although one student did the bulk of the 'explaining,' there was a lot of mathematical talk that was more than just asking questions or explaining. Students negotiated ways of working together that were less hierarchical and more collaborative. This study provides an interesting example of how some tasks may be inherently more equitable - by providing more ways for students to participate and be positioned as competent contributors to group success.

Of course, tasks may not be easily divided into procedural/rote or illstructured/complex categories. In a study contrasting two kinds of activity structures in three high school mathematics classes, it was found that the same task might be taken up differently in different groups, with some groups approaching the task as if it were a problem to figure out and solve, while others approached it as if there were a procedure to follow (Esmonde, 2006). Thus, although the selection of 'group-worthy' tasks (Lotan, 2003) is an important consideration for teachers, these tasks need to be accompanied with pedagogical techniques that encourage exploration and explanation, rather than only procedures and memorization.

\section{Assessment and group rewards that promote equity}

Slavin (1996) argues that the most critical consideration for effective cooperative learning is student motivation. Students have to be motivated not only to do the work, but also to do the work together. Many studies of cooperative learning have focused on how best to structure classroom activities to enhance student motivation, and therefore achievement (see, e.g., Fantuzzo, King, \& Heller, 1992; Ginsburg-Block \& Fantuzzo, 1998; R. J. Stevens \& Slavin, 1995). When interdependence is built into activities, groups 
tend to engage in more communication and consensus-building (Straus, 1999). Activity structures that incorporated group rewards (to support interdependence) and individual accountability were found to be most consistently effective (for a review of this literature, see Slavin, 1996).

However, these studies tend to describe only the context and the achievement outcomes, and to treat both motivation and participation as 'black boxes' (Bossert, 19881989). They do not measure directly how task structure affects motivation, or how either task structure or motivation affects participation. They do not discuss the kind of mathematical tasks that students engaged in. Some have argued that this type of activity encourages rote learning rather than deep conceptual understanding (Damon, 1984). As a result, these kinds of activities may foster inequitable positioning in the group, where some students are positioned as competent teachers, others as less capable (as described in Esmonde, Manuscript submitted for review). This inequity may become exacerbated when students feel there is not enough time for them to complete the task, or if they are being graded for correctness, rather than for a positive group process (Esmonde \& O'Connor, 2008).

The question of how to assess learning in cooperative classrooms has also proved to be controversial. Slavin's method calls for groups to be assessed by the progress of individuals within the group, but for some types of activities, like group projects or presentations, calling attention to individuals may actually undercut the emphasis on cooperation and joint sense-making. Individual assessment can encourage students to value their own learning more than that of their peers, but group assessments can allow students to 'free ride' and let the rest of the group do the work (Wilczenski, Bontrager, 
Ventrone, \& Correia, 2001). Proper assessment of group and individual learning remains an unresolved issue in the field.

$\underline{\text { Summarizing research on contexts, mathematics learning, and equity }}$

This review of status, roles and scripts, task content, assessment and rewards has covered a broad swath of research on cooperative learning. In an area of research that is marked by divergent theoretical and empirical paradigms, the above review has necessarily been disjointed because the studies do not always focus on the same issues or provide the same amount of detail. It is hard to compare a study of $3^{\text {rd }}$ grade students working once in pairs on a set of rote arithmetic problems, with a study of middle school students working in groups of four in a mathematics class based on problem-based learning, in which their mathematical goals emerge and are not known in advance. Although there is already a wealth of research on the use of cooperative learning in mathematics classrooms, still more is needed if we are to integrate all the concerns that have been raised across the different studies. At the very least, each study should provide enough detail about each of the four dimensions discussed here, so that they can more easily be compared and contrasted with one another.

Despite this complexity, there are still a number of generalizations that can be made at this point. In the long term, helping students to see that mathematics is more than just speedy calculation, and that each group member has something important to offer the group, can lay the groundwork for equity. Eventually, all students can be positioned as competent, allowing them to move towards central participation in mathematical practices. This is most easily done with tasks that are chosen carefully, to empirically demonstrate to students that each one of them is 'smart' and necessary to the group (i.e., 
group-worthy problems). Explicitly providing roles or training to students can help students to assume positions of authority in the group, and to explicitly teach students about valued discourse practices. Assessments should be thought through carefully, given the controversy of the topic, in ways that further support group collaboration.

While the studies cited above deal with many aspects of classroom context, there are several understudied areas. For example, although group work is often recommended to support the learning of English-language learner students, there have been few research studies that explicitly focused on how best to structure these activities so that ELL students are positioned as competent and necessary to their group success. Supporting students' first language use in mathematics learning is another recommended strategy (Echevarria, Vogt, \& Short, 2000). Gutierrez (2002) provides compelling examples of classrooms in which bilingual students used multiple languages in group work. More such studies could help illuminate which cooperative learning structures and contexts are most beneficial for ELL students.

A second gap in the research concerns one dimension of context that teachers do not typically have control over: the composition of their classrooms. Equity issues that arise in classrooms that are relatively homogeneous are different from those that arise in diverse classrooms. There is little research about whether particular techniques or cooperative activity structures are best suited to particular groups of students. While some have argued that culturally relevant pedagogy seems like 'just good teaching' (Ladson-Billings, 1995) and what is necessary for some students is probably beneficial for all (Hitchcock, Meyer, Rose, \& Jackson, 2002), there are particular issues that arise in classrooms in which privileged students mingle with marginalized students. 
For example, consider a classroom in which the students who come to be positioned as most competent are mostly or all White, English-monolingual, middle-class students. In my view, in such a classroom, a teacher's responsibility towards equity would include challenging the privilege of these students, and making space for students of color, working class students, and ELL students. Which pedagogical techniques should be used in this case? Consider, by contrast, an urban classroom in an underfunded neighborhood school, serving all African American students. In such a classroom, although a teacher might have a responsibility to provide equitable opportunities to learn to all students, the learning environment would not be complicated by the presence of more privileged students. As a third example, consider a classroom in a selective private school, including only children of a very wealthy, elite, mostly White population. What issues of equity arise in this case, and how can principles of multicultural education be applied here? The classroom composition, and beyond that, the place of that particular classroom in that school and in the wider educational landscape should be a subject of further research in this area.

A third aspect of context that is often ignored is student experience with group work. Collaboration is learned, and is situated in the practices of a particular community (Barron et al., 2007). The training studies, as well as studies of how status shifts over time, emphasize the fact that group processes change over time (Gillies, 2000; Gillies \& Ashman, 1998). Students with more experience in group work tend to benefit more from it (Veenman, Denessen, van den Akker, \& van der Rijt, 2005). Yet most research studies do not report how group work develops, and treat snapshots of classroom activity as 
representative of group work at all times and contexts. It would be useful to get a sense of how classroom social ecologies support the development of collaborative skills.

Future directions for research on equity and cooperative work in mathematics

I began this review with a set of questions about how the structure of cooperative learning in mathematics classrooms might support equity in terms of the distribution of opportunities to learn. In making sense of the vast body of research on mathematics learning in cooperative groups, I illustrated how the social ecology of the classroom supports particular kinds of group interactions, leading to particular kinds of learning outcomes. I also emphasized the need to consider learning in terms of access to mathematical ideas as well as mathematical and social identities. While in general the research findings support the notion it is more equitable when groups work towards intersubjectivity and position all students as valuable contributors, there were several important gaps in the research.

While some studies were quite detailed in outlining the types of mathematical tasks and activity structures, the classroom reward structure, and teacher efforts at positioning students with competence, others were less so. There is still a need for research into how various classroom ecologies support particular kinds of engagement with mathematical ideas and identities. At this point, the field could benefit from longterm ethnographic studies in classrooms where students regularly engage in cooperative work. In real classrooms, students frequently know one another well, and groups may not always be matched by gender or prior achievement. Groups work on a range of tasks from computational to conceptual - with a range of rewards - individual, group, or some combination of the two. As in any interaction, students manage the social space and the 
mathematical space simultaneously. Thus, real classrooms do not often fall into the categories so cleanly delineated in the literature. Such studies could begin to unpack some of the complexity of the relationships between the contextual dimensions described in the literature, and also focus closely on the relationship between individual, group, and classroom-level shifts in collective practices.

In addition, about the ecological approach suggests the importance of studying how social categories from beyond school (e.g., race, gender, socioeconomic status) mingle with categories that are constructed within schools (e.g., ability groups, popularity, sometimes friendship) and influence the nature of group interaction. It may be the case that different pedagogies are appropriate for different kinds of classrooms. For example, issues of status (and positioning) in a relatively homogeneous classroom of white middle-class students may play out very differently than they would in a highly heterogeneous classroom in terms of race, socioeconomic status, and prior achievement. Too much of the research on cooperative learning seems to assume that all learners and all classrooms are created equal.

A third area that I have suggested for future research was the connection between access to mathematical ideas and positive positional identities. While in interaction, the mathematical talk serves to position students, and acts of positioning often concern mathematical ideas, the relationship between positioning and content learning is not clear. If teachers wish to support more equitable group work in their mathematics classrooms, would their efforts be rewarded more by working on positioning, helping students learn to gain intersubjectivity with their group, or some combination? 
Finally, although this review has focused solely on the classroom setting and defined equity as a fair distribution of opportunities to learn, these ideas should be viewed in connection to broader issues of equity in schools and society. Not only do students of color disproportionately attend inner-city schools plagued with a lack of resources (Kozol, 2005), but within diverse schools, students of color and students with low socioeconomic status are frequently assigned to Special Education classes, placed in low-track classes, or otherwise deemed incapable of performing highly (Lucas, 1999; McDermott, Goldman, \& Varenne, 2006; Oakes, Joseph, \& Muir, 2003). Teacher beliefs about their students play a prominent role in what they do in their classrooms (Rousseau $\&$ Tate, 2003), as do contextual factors such as time, curriculum available, and teacher professional development (Rousseau \& Powell, 2005), and there is ample evidence that what teachers do matters quite a bit for student achievement, persistence, and processes of positioning and identification (Perry, 2003). In mathematics education, all of these aspects of schooling, and the relationships between them, need to be taken into account if we are to make real progress towards equity. 


\section{References}

Ainsworth-Darnell, J., \& Downey, D. (1998). Assessing the oppositional culture explanation for racial/ethnic differences in school performance. American Sociological Review.

Allexsaht-Snider, M., \& Hart, L. E. (2001). "Mathematics for all": How do we get there? Theory into Practice, 40(2), 93-101.

Anderson, C. W., Holland, J. D., \& Palincsar, A. S. (1997). Canonical and sociocultural approaches to research and reform in science education: The story of Juan and his group. The Elementary School Journal, 97(4), 359-383.

Anderson, D. D., \& Gold, E. (2006). Home to school: Numeracy practices and mathematical identities. Mathematical Thinking and Learning, 8(3), 261-286.

Antil, L. R., Jenkins, J. R., Wayne, S. K., \& Vadasy, P. F. (1998). Cooperative learning: Prevalence, conceptualizations, and the relation between research and practice. American Educational Research Journal, 35(3), 419-454.

Aronson, E., \& Bridgeman, D. (1979). Jigsaw groups and the desegregated classroom: In pursuit of common goals. Personality and social psychology bulletin, 5(4), 438446.

Ashman, A. F., \& Gillies, R. M. (1997). Children's cooperative behavior and interactions in trained and untrained work groups in regular classrooms. Journal of School Psychology, 35(3), 261-279.

Azmitia, M. (1988). Peer Interaction and Problem Solving: When Are Two Heads Better Than One? Child Development, 59(1), 87-96.

Azmitia, M., \& Montgomery, R. (1993). Friendship, transactive dialogues, and the development of scientific reasoning. Social Development, 2(3), 202-221.

Baker, D., Street, B., \& Tomlin, A. (2006). Navigating schooled numeracies: Explanations for low achievement, in mathematics of UK children from low SES background. Mathematical Thinking and Learning, 8(3), 287-307.

Baker, J. (2002). Trilingualism. In L. Delpit \& J. K. Dowdy (Eds.), The skin that we speak: Thoughts on language and culture in the classroom (pp. 49-62). New York: The New Press.

Ball, D. (2002). Knowing mathematics for teaching: Relations between research and practice. Mathematics and Education Reform Newsletter, 14(3), 1-5.

Ballenger, C. (1999). Teaching other people's children: Literacy and learning in a bilingual classroom. New York : Teachers College Press.

Barron, B. (2000). Achieving coordination in collaborative problem-solving groups. The Journal of the Learning Sciences, 9(4), 403-436.

Barron, B. (2003). When smart groups fail. Journal of the Learning Sciences, 12(3), 307359.

Barron, B., Casillas, N., Esmonde, I., Herrenkohl, L. R., Mercier, E., Mertl, V., et al. (2007, April). Collaborative capacities as a component of adaptive expertise. Paper presented at the annual meeting of the American Educational Research Association, Chicago, IL.

Barwell, R. (2005). Integrating language and content: Issues from the mathematics classroom. Linguistics and Education, 16(2), 205-218. 
Baxter, J. A., Woodward, J., \& Olson, D. (2001). Effects of reform-based mathematics instruction on low achievers in five third-grade classrooms. Elementary School Journal, 101(5), 529-547.

Becker, J. R. (1995). Women's ways of knowing in mathematics. In P. Rogers \& G. Kaiser (Eds.), Equity in mathematics education (pp. 163-175). London: The Falmer Press.

Berger, J. B., Cohen, B. P., \& Zelditch, M., Jr. (1972). Status characteristics and social interaction. American Sociological Review, 37, 241-255.

Berry, R. Q. (2003). Mathematics standards, cultural styles, and learning preferences: The plight and the promise of African American students. The Clearing House, 76(5), 244-249.

Bianchini, J. A. (1997). Where knowledge construction, equity, and context intersect: Student learning of science in small groups. Journal of Research in Science Teaching, 34(10), 1039-1065.

Bianchini, J. A. (1999). From here to equity: The influence of status on student access to and understanding of science. Science Education, 83(5), 577-601.

Bishop, A. (2001). What values do you teach when you teach mathematics? In P. Gates (Ed.), Issues in Mathematics Teaching (pp. 93-104). London and New York: RoutledgeFarmer.

Black, L. (2004). Teacher-pupil talk in whole-class discussions and processes of social positioning within the primary school classroom. Language and education, 18(5), 347-360.

Boaler, J. (2002). Paying the price for "sugar and spice": Shifting the analytical lens in equity research. Mathematical Thinking and Learning, 4(2\&3), 127-144.

Boaler, J. (In press). Promoting 'relational equity' and high mathematics achievement through an innovative mixed ability approach. British Educational Research Journal.

Boaler, J., Cobb, P. A., Gresalfi, M. S., Horn, I. S., Hodge, L. L., \& Staples, M. E. (2006). Equity and identity in mathematics classrooms: Students' learning opportunities, knowledge orientation, persistence, and "future selves". Paper presented at the annual meeting of the American Educational Research Association, San Francisco, CA.

Boaler, J., \& Staples, M. E. (In press). Creating mathematical futures through an equitable teaching approach: The case of Railside School. Teachers' College Record.

Bossert, S. T. (1988-1989). Cooperative activities in the classroom. Review of Research in Education, 15, 225-250.

Boykin, A. W. (1986). The triple quandary and the schooling of Afro-American children. In U. Neisser (Ed.), The school achievement of minority children: New perspectives (pp. 57-92). Hillsdale, New Jersey.

Bronfenbrenner, U. (1979). The ecology of human development: Experiments by nature and design. Cambridge, MA: Harvard University Press.

Brown, A. L., \& Palincsar, A. S. (1989). Guided, Cooperative Learning and Individual Knowledge Acquisition. In L. B. Resnick (Ed.), Knowing, Learning, and Instruction: Essays in Honor of Robert Glaser. Hillsdale, New Jersey: Lawrence Erlbaum Associates. 
Buchs, C., Butera, F., Mugny, G., \& Darnon, C. (2004). Conflict elaboration and cognitive outcomes. Theory into Practice, 43(1), 23-30.

Buxton, C. A. (2003). Creating a culture of academic success in an urban science and math magnet high school. Science Education, 89(3), 392-417.

Carter, G., Jones, M. G., \& Rua, M. (2003). Effects of partner's ability on the achievement and conceptual organization of high-achieving fifth-grade students. Science Education, 87(1), 94-111.

Chizhik, A. W. (2001). Equity and status in group collaboration: Learning through explanations depends on task characteristics. Social Psychology of Education, 5, 179-200.

Civil, M. (2007). Building on community knowledge: An avenue to equity in mathematics education. In N. i. S. Nasir \& P. Cobb (Eds.), Improving access to mathematics: Diversity and equity in the classroom (pp. 105-117). New York, NY: Teachers College Press.

Clarke, J. (1994). Pieces of the puzzle: The jigsaw method. In S. Sharan (Ed.), Handbook of cooperative learning methods (pp. 34-50). Westport, CT: Greenwood Press.

Cobb, P., \& Hodge, L. L. (2002). A relational perspective on issues of cultural diversity and equity as they play out in the mathematics classroom. Mathematical Thinking and Learning, 4(2-3), 249-284.

Cohen, E. G. (1982). Expectation States and Interracial Interaction in School Settings. Annual Review of Sociology, 8, 209-235.

Cohen, E. G. (1994). Restructuring the classroom: Conditions for productive small groups. Review of Educational Research, 64(1), 1-35.

Cohen, E. G., \& Goodlad, J. I. (1994). Designing groupwork: Strategies for the heterogeneous classroom (2nd ed.). New York: Teachers College Press.

Cohen, E. G., \& Lotan, R. A. (Eds.). (1997). Working for equity in heterogeneous classrooms: Sociological theory in practice. New York: Teachers College Press.

Cohen, E. G., Lotan, R. A., Scarloss, B. A., \& Arellano, A. R. (1999). Complex instruction: Equity in cooperative learning classrooms. Theory into Practice, $38(2), 80-86$.

Cole, M. (1996). Cultural psychology: A once and future discipline. Cambridge, Mass.: Belknap Press of Harvard University Press.

Cotton, T. (2001). Mathematics teaching in the real world. In P. Gates (Ed.), Issues in Mathematics Teaching (pp. 23-37). London and New York: RoutledgeFalmer.

Damon, W. (1984). Peer education: The untapped potential. Journal of Applied Developmental Psychology, 5(4), 331-343.

Davies, B., \& Harré, R. (1990). Positioning: The discursive production of selves. Journal for the Theory of Social Behavior, 20, 43-63.

de Abreu, G. (1995). Understanding how children experience the relationship between home and school mathematics. US: Lawrence Erlbaum.

de Corte, E. (2004). Mainstreams and perspectives in research on learning (mathematics) from instruction. A pplied Psychology: An international review, 53(2), 279-310.

de Haan, M., \& Elbers, E. (2005). Reshaping diversity in a local classroom: Communication and identity issues in multicultural schools in the Netherlands. Language and Communication, 25, 315-333. 
Dembo, M. H., \& McAuliffe, T. J. (1987). Effects of perceived ability and grade status on social interaction and influence in cooperative groups. Journal of Educational Psychology, 79(4), 415-423.

Dougherty, K. J. (1996). Opportunity-to-learn standards: A sociological critique. Sociology of Education(extra issue), 40-65.

Echevarria, J., Vogt, M., \& Short, D. J. (2000). Making Content Comprehensible for English Language Learners: The SIOP Model. Boston: Allyn and Bacon.

Elliott, M. (1998). School Finance and Opportunities to Learn: Does Money Well Spent Enhance Students' Achievement? Sociology of Education, 71, 223-245.

Enyedy, N., \& Mukhopadhyay, S. (2007). They don't show nothing I didn't know: Emergent tensions between culturally relevant pedagogy and mathematics pedagogy. Journal of the Learning Sciences, 16(2), 139-174.

Erickson, F. (2004). Talk and social theory: Ecologies of speaking and listening in everyday life. Cambridge, UK ; Malden, MA: Polity Press.

Esmonde, I. (2006). "How are we supposed to, like, learn it, if none of us know?": Opportunities to learn and equity in mathematics cooperative learning structures. Unpublished doctoral dissertation, University of California, Berkeley.

Esmonde, I. (2007). Equity and opportunities to learn in cooperative mathematical work. In P. Liljedahl (Ed.), Proceedings of the Annual Meeting of the Canadian Mathematics Education Study Group (pp. 103-110): CMESG.

Esmonde, I. (Manuscript submitted for review). Mathematics learning in groups: Analysing equity in two cooperative activity structures.

Esmonde, I., \& Langer-Osuna, J. (2007, April). Power in numbers: An analysis of how shifts in social and mathematical power among students in a cooperative group affect opportunities for learning. Paper presented at the annual meeting of the American Educational Research Association, Chicago, IL.

Esmonde, I., \& O'Connor, K. (2008). Mathematics collaboration as situated practice. Paper presented at the annual meeting of the American Educational Research Association. Retrieved.

Fantuzzo, J. W., King, J. A., \& Heller, J. R. (1992). Effects of reciprocal peer tutoring on mathematics and school adjustment: A component analysis. Journal of Educational Psychology, 84(3), 331-339.

Farivar, S., \& Webb, N. M. (1994). Helping and Getting Help--Essential Skills for Effective Group Problem Solving. A rithmetic Teacher, 41(9), 521-525.

Fawcett, L. M., \& Garton, A. F. (2005). The effect of peer collaboration on children's problem-solving ability. British Journal of Educational Psychology, 75, 157-169.

Flores, A. (2007). Examining disparities in mathematics education: Achievement gap or opportunity gap? The High School Journal, 91(1), 29-42.

Gee, J. P. (1996). Social linguistics and literacies: Ideology in discourses (2nd ed.). London ; Bristol, PA: Taylor \& Francis.

Gee, J. P. (2000). Identity as an Analytic Lens for Research in Education. Review of Research in Education, 25, 99-125.

Gillies, R. M. (2000). The maintenance of cooperative and helping behaviours in cooperative groups. British Journal of Educational Psychology, 70, 97-111. 
Gillies, R. M., \& Ashman, A. F. (1998). Behavior and interactions of children in cooperative groups in lower and middle elementary grades. Journal of Educational Psychology, 90(4), 746-757.

Ginsburg-Block, M. D., \& Fantuzzo, J. W. (1998). An evaluation of the relative effectiveness of NCTM Standards-based interventions for low-achieving urban elementary students. Journal of Educational Psychology, 90(3), 560-569.

Gonzalez, N., Andrade, R., Civil, M., \& Moll, L. (2001). Bridging funds of distributed knowledge: Creating zones of practices in mathematics. Journal of Education for Students Placed at Risk (JESPAR), 6(1-2), 115-132.

Good, T. L., McCaslin, M. M., \& Reys, B. J. (1992). Investigating work groups to promote problem solving in mathematics. In J. Brophy (Ed.), Advances in research on teaching, Volume 3: Planning and managing learning tasks and activities (pp. 115-160). Greenwich, CT: JAI Press Inc.

Gutiérrez, K. D. (2002). Studying cultural practices in urban learning communities. Human Development, 45(4), 312-321.

Gutierrez, K. D., \& Rogoff, B. (2003). Cultural ways of learning: Individual traits or repertoires of practice. Educational Researcher, 32(5), 19-25.

Gutierrez, R. (2002). Beyond essentialism: The complexity of language in teaching mathematics to Latino/a students. A merican Educational Research Journal, 39(4), 1047-1088.

Hand, V. (under review). Competent opposition: The negotiation of competing activity structures within a low-track mathematics classroom.

Hatano, G., \& Inagaki, K. (1991). Sharing cognition through collective comprehension activity. In R. L. Resnick, J. Levine \& S. Teasley (Eds.), Perspectives on socially shared cognition (pp. 341-348). Washington, DC: American Psychological Association.

Herrenkohl, L. R., Palincsar, A. S., DeWater, L. S., \& Kawasaki, K. (1999). Developing scientific communities in classrooms: A sociocognitive approach. The Journal of the Learning Sciences, 8(3\&4), 451-493.

Hitchcock, C., Meyer, A., Rose, D., \& Jackson, R. (2002). Providing new access to the general curriculum: Universal design for learning. Teaching Exceptional Children, 35(2), 8-17.

Hodge, L. L. (2006). An orientation on the mathematics classroom that emphasizes power and identity: Reflecting on equity research. The Urban Review, 38(5), 373385.

Hogan, K. (1999). Sociocognitive roles in science group discourse. International Journal of Science Education, 21(8), 855-882.

Holland, D., Lachiotte Jr., W., Skinner, D., \& Cain, C. (2001). Identity and agency in cultural worlds. Cambridge, Mass: Harvard University Press.

Howe, C., McWilliam, D., \& Cross, G. (2005). Chance favors only the prepared mind: Incubation and the delayed effects of peer collaboration. British Journal of Psychology, 96(1), 67-93.

Howe, C., Tolmie, A., \& Rodgers, C. (1992). The acquisition of concpetual knowledge in science by primary school children: Group interaction and the understanding of motion down an incline. British Journal of Developmental Psychology, 10, 113130. 
Humphreys, P., \& Berger, J. (1981). Theoretical consequences of the status characteristics formulation. American Journal of Sociology, 86(5), 953-983.

Jacobs, J. E., Becker, J. R., \& Gilmer, G. F. (2001). Changing the faces of mathematics: perspectives on gender. Reston, Va: NCTM.

Johnson, D. W., \& Johnson, R. T. (1991). Learning together and alone: Cooperative, competitive and individualistic learning. Englewood Cliffs, N.J.: Prentice hall.

Johnson, D. W., Johnson, R. T., \& Smith, K. A. (2000). Constructive controversy: The educative power of intellectual conflict. Change, 28-37.

Kelly, C. A. (2002). Creating equitable classroom climates: An investigation of classroom strategies in mathematics and science instruction for developing preservice teachers' use of democratic social values. Child Study Journal, 32(1), $39-51$.

Kilpatrick, J. (1992). A history of research in mathematics education. In D. A. Grouws (Ed.), Handbook of Research on Mathematics Teaching and Learning (pp. 3-38). New York: MacMillan.

King, A. (1991). Effects of training in strategic questioning on children's problem-solving performance. Journal of Educational Psychology, 83(3), 307-317.

King, A. (1994). Guiding knowledge construction in the classroom: Effects of teaching children how to question and how to explain. American Educational Research Journal, 31(2), 338-368.

King, A. (1997). ASK to THINK-TEL WHY®@: A model of transactive peer tutoring for scaffolding higher level complex learning. Educational Psychology, 32(4), 221-235.

King, L. H. (1993). High and low achievers' perceptions and cooperative learning in two small groups. The Elementary School Journal, 93(4), 399-416.

Kozol, J. (2005). The shame of the nation: The restoration of apartheid schooling in America. New York: Crown Publishers.

Ladson-Billings, G. (1995). But that's just good teaching! The case for culturally relevant pedagogy. Theory into Practice, 34(3), 159-165.

Lave, J., \& Wenger, E. (1991). Situated learning: Legitimate peripheral participation. Cambridge, UK: Cambridge University Press.

LeBlanc, G., \& Bearison, D. J. (2004). Teaching and learning as a bi-directional activity: Investigating dyadic interactions between child teachers and child learners. Cognitive Development, 19, 499-515.

Lee, C. D. (2008). Intervention research based on current views of cognition and learning. In J. E. King (Ed.), Black Education: Transformative Research and Action Agenda for the New Century (pp. 73-114). Mahwah, NJ: Lawrence Erlbaum Associates.

Lee, C. D. (in preparation). A cultural modeling perspective on OTL: The creation of opportunity to learn through the cultural practices of classroom instruction.

Lee, J. (2002). Racial and ethnic achievement gap trends: Reversing the progress toward equity? Educational Researcher, 31(1), 3-12.

Lerman, S. (2000). A case of interpretations of social: A response to Steffe and Thompson. Journal for Research in Mathematics Education, 31(2), 210-227. 
Lerman, S. (2001). Cultural, discursive psychology: A sociocultural approach to studying the teaching and learning of mathematics. Educational Studies in Mathematics, 46(1-3), 87-113.

Lopez-Reyna, N. A. (1997). Reflections on the positive effects of cooperative learning structures. Exceptionality, 7(4), 273-275.

Lotan, R. A. (2003). Group-worthy tasks. Educational Leadership, 60(7), 72-75.

Lubienski, S. T. (2002). Research, reform, and equity in U.S. mathematics education. Mathematical Thinking and Learning, 4(2 \& 3), 103-125.

Lubienski, S. T. (2007). Research, reform, and equity in U.S. mathematics education. In N. i. S. Nasir \& P. Cobb (Eds.), Improving access to mathematics: Diversity and equity in the classroom. New York: Teachers College Press.

Lucas, S. R. (1999). Tracking inequality: Stratification and mobility in American high schools. New York: Teacher's College Press.

Lucey, H., Melody, J., \& Walkerdine, V. (2003). Uneasy hybrids: Psychosocial aspects of becoming educationally successful for working-class young women. Gender and education, 15(3), 285-299

Martin, D. B. (2000). Mathematics success and failure among African-A merican youth: The roles of sociohistorical context, community forces, school influence, and individual agency. Mahwah, N.J.: Lawrence Erlbaum.

Martin, D. B. (2006). Mathematics learning and participation as racialized forms of experience: African American parents speak on the struggle for mathematics literacy. Mathematical Thinking and Learning, 8(3), 197-229.

McAdams, D. P., \& Bowman, P. J. (2001). Narrating life's turning points: Redemption and contamination. In D. P. McAdams, R. Josselson \& A. Lieblich (Eds.), Turns in the road: Narrative studies of lives in transition (pp. 3-34). Washington, DC: American Psychological Association.

McAuliffe, T. J., \& Dembo, M. H. (1994). Status rules of behavior in scenarios of peer learning. Journal of Educational Psychology, 86(2), 163-172.

McDermott, R., Goldman, S., \& Varenne, H. (2006). The cultural work of learning disabilities. Educational Researcher, 35(6), 12-17.

McPartland, J. M., \& Schneider, B. (1996). Opportunities to learn and student diversity: Prospects and pitfalls of a common core curriculum. Sociology of Education, 69(extra issue), 66-81.

Mendick, H. (2005). A beautiful myth? The gendering of being/doing 'good at maths'. Gender and education, 17(2), 203-219.

Mercier, E. (2008). Group goals: Their influence on interaction patterns and learning. Stanford University, Stanford, CA.

Mitchell, S. N., Reilly, R., Bramwell, F. G., Solnosky, A., \& Lilly, F. (2004). Friendship and choosing groupmates: Preferences for teacher-selected vs. student-selected groupings in high school science classes. Journal of Instructional Psychology, $31(1), 20-32$.

Moschkovich, J. (2002). A Situated and Sociocultural Perspective on Bilingual Mathematics Learners. Mathematical Thinking and Learning, 4(2-3), 189-212.

Moses, R. P., \& Cobb, C. E. (2001). Radical equations: Math literacy and civil rights. Boston: Beacon Press. 
Mulryan, C. M. (1992). Student Passivity during Cooperative Small Groups in Mathematics. Journal of Educational Research, 85(5), 261-273.

Mulryan, C. M. (1994). Perceptions of Intermediate Students' Cooperative Small-Group Work in Mathematics. Journal of Educational Research, 87(5), 280-291.

Mulryan, C. M. (1995). Fifth and Sixth Graders' Involvement and Participation in Cooperative Small Groups in Mathematics. Elementary School Journal, 95(4), 297-310.

Nasir, N. i. S., \& Hand, V. (2006). Exploring sociocultural perspectives on race, culture, and learning. Review of Educational Research, 76(4), 449-475.

Nasir, N. i. S., Rosebery, A. S., Warren, B., \& Lee, C. D. (2006). Learning as a cultural process: Achieving equity through diversity. In R. K. Sawyer (Ed.), The Cambridge Handbook of the Learning Sciences (pp. 489-504). Cambridge: Cambridge University Press.

Nathan, M. J., Eilam, B., \& Kim, S. (2007). To disagree, we must also agree: How intersubjectivity structures and perpetuates discourse in a mathematics classroom. Journal of the Learning Sciences, 16(4), 523-563.

Nattiv, A. (1994). Helping Behaviors and Math Achievement Gain of Students Using Cooperative Learning. The Elementary School Journal, 1994(94), 3.

NCTM. (2000). Principles and Standards for School Mathematics: An Overview. Reston, VA: The National Council of Teachers of Mathematics.

NCTM Research Committee. (2005). Equity in School Mathematics Education: How Can Research Contribute? Journal for Research in Mathematics Education, 36(2), 92100.

O'Donnell, A. M. (2006). The role of peers and group learning. In P. A. Alexander \& P. H. Winne (Eds.), Handbook of Educational Psychology (2nd ed., pp. 781-802). Mahway, New Jersey: Lawrence Erlbaum Associates.

O'Donnell, A. M., Dansereau, D. F., Hall, R. H., Skaggs, L. P., Hythecker, V. I., Peel, J. F., et al. (1990). Learning concrete procedures: Effects of processing strategies and cooperative learning. Journal of Educational Psychology, 82(1), 171-177.

Oakes, J., Joseph, R., \& Muir, K. (2003). Access and Achievement in Mathematics and Science: Inequalities that Endure and Change. In J. A. Banks \& C. A. M. Banks (Eds.), Handbook of Research on Multicultural Education (2nd ed., Vol. 2). San Francisco: Jossey Bass.

Olivera, F., \& Straus, S. G. (2004). Group-to-individual transfer of learning: Cognitive and social factors. Small Group Research, 35, 440-465.

Perrenet, J., \& Terwel, J. (1997). Interaction patterns in cooperative groups: The effects of gender, ethnicity, and ability. Paper presented at the annual meeting of the American Educational Research Association, Chicago, IL.

Perry, T. (2003). Up from the parched earth: Toward a theory of African-American achievement. In Young, gifted and black: Promoting high achievement among African-A merican students (pp. 1-108). Boston: Beacon Press.

Phelps, E., \& Damon, W. (1989). Problem solving with equals: Peer collaboration as a context for learning mathematics and spatial concepts. Journal of Educational Psychology, 81(4), 639-646.

Porter, A. (1995). The uses and misuses of opportunity-to-learn standards. Educational Researcher, 24(1), 21-27. 
Rodd, M., \& Bartholomew, H. (2006). Invisible and special: Young women's experiences as undergraduate mathematics students. Gender and education, 13(1), 35-50.

Rogoff, B. (1990). A pprenticeship in thinking : cognitive development in social context. New York: Oxford University Press.

Rogoff, B. (2003). The cultural nature of human development. New York: Oxford University Press.

Rohrbeck, C. A., Ginsburg-Block, M. D., Fantuzzo, J. W., \& Miller, T. R. (2003). Peerassisted learning interventions with elementary school students: A meta-analytic review. Journal of Educational Psychology, 95(2), 240-257.

Ross, J. A. (1995). Effects of feedback on student behavior in cooperative learning groups in a Grade 7 math class. The Elementary School Journal, 96(2), 125-143.

Ross, J. A., Haimes, D. H., \& Hogaboam-Gray, A. (1996). Improving student helpfulness in cooperative learning groups. Journal of Classroom Interaction, 31(2), 13-22.

Rousseau, C., \& Powell, A. (2005). Understanding the significance of context: A framework to examine equity and reform in secondary mathematics. High School Journal, 88(4), 19-31.

Rousseau, C., \& Tate, W. F. (2003). No time like the present: Reflecting on equity in school mathematics. Theory into Practice, 42(3), 210-216.

Sawyer, R. K., \& Berson, S. (2004). Study group discourse: How external representations affect collaborative conversation. Linguistics and Education, 15(4), 387-412.

Saxe, G. B. (1991). Culture and cognitive development: Studies in mathematical understanding. Hillsdale, NJ: Lawrence Erlbaum Associates.

Saxe, G. B. (1999). Cognition, development, and cultural practices. New Directions for Child and Adolescent Development(83), 19-35.

Saxe, G. B., Gearhart, M., Note, M., \& Paduano, P. (1993). Peer interaction and the development of mathematical understandings: A new framework for research and educational practice. In H. Daniels (Ed.), Charting the agenda: Educational activity after Vygotsky (pp. 107-144). London: Routledge.

Schegloff, E. A. (1991). Conversation analysis and socially shared cognition. In R. L. Resnick, J. Levine \& S. Teasley (Eds.), Perspectives on socially shared cognition (pp. 150-171). Washington, DC: American Psychological Association.

Schoenfeld, A. H. (2002). Making mathematics work for all children: Issues of standards, testing, and equity. Educational Researcher, 31(1), 13-25.

Schwartz, D. L., \& Martin, T. (2004). Inventing to prepare for future learning: The hidden efficiency of encouraging original student production in statistics instruction. Cognition and Instruction, 22(2), 129-184.

Schwartz, D. L., \& Okita, S. (Submitted for publication). The productive agency in learning by teaching.

Secada, W. (1989). Educational equity versus equality of education: An alternative conception. In W. Secada (Ed.), Equity in education (pp. 68-88). New York: Falmer Press.

Secada, W. (2000). Changing the faces of mathematics: perspectives on multiculturalism and gender equity. Reston, VA: NCTM.

Sfard, A., \& Prusak, A. (2005). Telling identities: In search of an analytic tool for investigating learning as a culturally shaped activity. Educational Researcher, $34(4), 14-22$. 
Sharan, S. (Ed.). (1999). Handbook of Cooperative Learning Methods. Westport, CT: Praeger.

Shelly, R. K., \& Troyer, L. (2001). Emergence and completion of structure in initially undefined and partially defined groups. Social Psychology Quarterly, 64(4), 318332.

Slavin, R. E. (1996). Research on Cooperative Learning and Achievement: What We Know, What We Need to Know. Contemporary Educational Psychology, 21(1), 43-69.

Slavin, R. E., \& Cooper, R. (1999). Improving intergroup relations: lessons learned from cooperative learning programs. Journal of Social Issues, 55(4), 647-663.

Solomon, Y. (1998). Teaching mathematics: Ritual, principle and practice. Journal of Philosophy of Education, 32(3), 377-390.

Steele, C. M., Spencer, S. J., \& Aronson, J. (2002). Contending with group image: The psychology of stereotype and social identity threat. Advances in experimental social psychology, 34, 379-440.

Stevens, R. (2000). Who counts what as math? Emergent and assigned mathematics problems in a project-based classroom. In J. Boaler (Ed.), Multiple perspectives on mathematics teaching and learning (pp. 105-144). Westport, CT: Ablex Publishing.

Stevens, R. J., \& Slavin, R. E. (1995). The cooperative elementary school: Effects on students' achievement, attitudes, and social relations. A merican Educational Research Journal, 32(2), 321-351.

Straus, S. G. (1999). Testing a typology of tasks: An empirical validation of McGrath's (1984) group task circumplex. Small Group Research, 30(2), 166-187.

Strough, J., Berg, C. A., \& Meegan, S. P. (2001). Friendship and gender differences in task and social interpretations of peer collaborative problem solving. Social Development, 10(1), 1-22.

Tate, W. F. (1995). School mathematics and African American students: Thinking seriously about opportunity-to-learn standards. Educational Administration Quarterly, 31, 424-448.

Tate, W. F. (1997). Race-ethnicity, SES, gender, and language proficiency trends in mathematics achievement: An update. Journal for Research in Mathematics Education, 28(6), 652-679.

Trentacosta, J., \& Kenney, M. J. (1997). Multicultural and Gender Equity in the Mathematics Classroom: The Gift of Diversity. Reston, VA: NCTM.

Veenman, S., Denessen, E., van den Akker, A., \& van der Rijt, J. (2005). Effects of a cooperative learning program on the elaborations of students during help seeking and help giving. American Educational Research Journal, 42(1), 115-151.

Vygotsky, L. S. (1978). Mind in society: The development of higher psychological processes. Cambridge, Massachusetts: Harvard University Press.

Vygotsky, L. S. (1986). Thought and language (A. Kozulin, Trans.). Cambridge, Massachusetts: The MIT Press.

Walker, E. N. (2006). Urban high school students' academic communities and their effects on mathematics success. American Educational Research Journal, 43(1), 43-78. 
Walshaw, M. (2005). Getting political and unraveling layers of gendered mathematical identifications. Cambridge Journal of Education, 35(1), 19-34.

Webb, N. M. (1984). Sex Differences in Interaction and Achievement in Cooperative Small Groups.

Webb, N. M. (1989). Peer interaction and learning in small groups. International Journal of Educational Research, 13(1), 21-39.

Webb, N. M. (1991). Task-Related Verbal Interaction and Mathematics Learning in Small Groups. Journal for Research in Mathematics Education, 22(5), 366-389.

Webb, N. M., \& Farivar, S. H. (1994). Promoting helping behavior in cooperative small groups in middle school mathematics. A merican Educational Research Journal, 31(2), 369-395.

Webb, N. M., Farivar, S. H., \& Mastergeorge, A. M. (2002). Productive Helping in Cooperative Groups. Theory into Practice, 41(1), 13-20.

Webb, N. M., \& Mastergeorge, A. M. (2003). The development of students' helping behavior and learning in peer-directed small groups. Cognition and Instruction, 21(4), 361-428.

Webb, N. M., Nemer, K. M., \& Zuniga, S. (2002). Short circuits or superconductors? Effects of group composition on high-achieving students' science assessment performance. American Educational Research Journal, 39(4), 943-989.

Webb, N. M., \& Palincsar, A. S. (1996). Group processes in the classroom. In D. C. Berliner \& R. C. Calfee (Eds.), Handbook of Educational Psychology (pp. 841873). New York, NY: Macmillan Library Reference Usa.

Weinstein, C., Curran, M., \& Tomlinson-Clarke, S. (2003). Culturally responsive classroom management: Awareness into action. Theory into Practice, 42(4), 269276.

Weissglass, J. (2000). No compromise on equity in mathematics education: Developing an infrastructure. In W. Secada (Ed.), Changing the Faces of Mathematics: Multiculturalism and Gender Equity (pp. 5-24). Reston, VA: NCTM.

Wenger, E. (1998). Communities of practice: Learning, meaning, and identity. Cambridge, U.K: Cambridge University Press.

Wertsch, J. V. (1984). The Zone of Proximal Development: Some Conceptual Issues. In B. Rogoff \& J. V. Wertsch (Eds.), Children's Learning in the Zone of Proximal Development (Vol. no. 23, pp. 7-18). San Francisco: Jossey-Bass.

Wilczenski, F. L., Bontrager, T., Ventrone, P., \& Correia, M. (2001). Observing collaborative problem-solving processes and outcomes. Psychology in the Schools, 38(3), 269-281.

Woodson, C. (1933/1972). The mis-education of the Negro. New York: AMS Press.

Yackel, E., Cobb, P., \& Wood, T. (1991). Small-group interactions as a source of learning opportunities in second-grade mathematics. Journal for Research in Mathematics Education, 22(5), 390-408

Yackel, E., Cobb, P., \& Wood, T. (1999). The interactive constitution of mathematical meaning in one second grade classroom: An illustrative example. Journal of Mathematical Behavior, 17(4), 469-488.

Zajac, R. J., \& Hartup, W. W. (1997). Friends as coworkers: Research review and classroom implications. The Elementary School Journal, 98(1), 3-13. 


\section{Author Note}

This work was supported by the National Science Foundation under Grant No. ESI0119732 to the Diversity in Mathematics Education Center for Learning and Teaching, and Grant No. SBE-0354453 to the Learning in Informal and Formal Environments Science of Learning Center, as well as by the Connaught Fund at the University of Toronto. Any opinions, findings, and conclusions or recommendations expressed in this material are those of the author(s) and do not necessarily reflect the position, policy, or endorsement of the National Science Foundation or the Connaught Fund.

I would like to thank Geoffrey B. Saxe, Alan Schoenfeld, Patricia BaquedanoLopez, Samuel R. Lucas, Brigid Barron, Meg Meyer, Emma Mercier, Angela Booker, Aditya Johri, Lee Martin, Lance McCready, Joseph Flessa, and Rubèn GaztambideFernandez for their careful reading and thoughtful critique of earlier versions of this paper.

Correspondence concerning this article should be addressed to Indigo Esmonde, Ontario Institute for Studies in Education, University of Toronto, 252 Bloor St. W., Toronto, Ontario, Canada, M5S 1V6. Electronic mail may be sent to iesmonde@oise.utoronto.ca. 


\section{Footnotes}

1. Equity in educational contexts is complex and multi-faceted, encompassing differences in resources, quality of instruction, and differences in outcomes (Allexsaht-Snider \& Hart, 2001). There are multiple factors that influence these outcomes, including teacher beliefs and actions, classroom processes, school-level structures such as tracking and course-counseling, and community-level issues. In this review, I focus on the classroom level and cooperative group work because cooperative learning is often used as a way to move towards equity in educational outcomes and processes. I return to broader definitions and questions about equity in the discussion section.

2. It is important to note here that by 'participation,' I do not mean talk, although talk is empirically often the simplest thing to observe. While talk is a valued form of participation in many mathematics classrooms, there may be other valuable forms of participation that are less visible.

3. Gee uses Discourse (with a capital D) to distinguish it from the term discourse (lower case d) that is often used to refer simply to talk, divorced from other communicative modalities (e.g., gesture) and from the social meaning emphasized by Gee. I will use a lower case $\mathrm{d}$ when referring to research that emphasizes properties of talk only, and a capital D when following Gee's definition. 